\title{
Histopathological Examination of the Effects of Butane Gas on Nasal Mucosa in Rats S Yaslikaya ${ }^{1}$, I Topaloglu ${ }^{2}$, G Hafiz $^{3}$
}

\begin{abstract}
Objective: Butane is present as propellant gas in deodorants, shaving foam tubes, air fresheners. In our study, potential allergic effects of chronic inhalation of butane on nasal mucosa of rats were evaluated.

Methods: An experimental study was conducted on Wistar Albino rats. Animals were divided into two groups as experimental and control. Butane was exposed to the experimental group for 100 days. Five micron-thick coronal slices were taken from the nasal cavities of the animals. Eosinophils, goblet cells, lymphocytes and eosinophil exocytosis were evaluated in slices. Results: An increase was found in eosinophil counts in experimental group ( $\mathrm{p}<$ 0.001), between the groups lymphocyte infiltration, amount of goblet cells and eosinophil exocytosis was found similar $(\mathrm{p}>0.05)$. A positively correlation was observed between lymphocyte infiltration and eosinophil exocytosis in experimental group $(\mathrm{p}=0.0001)$.
\end{abstract}

Conclusion: According to our study butane may create inflammation in nasal mucosa

Keywords: Butane, eosinophil, goblet, nasal

From: ${ }^{1}$ Department of Otorhinolaryngology, Kanuni Sultan Suleyman Education and Research Hospital, Istanbul, Turkey, ${ }^{2}$ Faculty of Medicine, Yeditepe University, Istanbul, Turkey, ${ }^{3}$ Istanbul Faculty of Medicine, Istanbul University, Istanbul, Turkey.

Correspondence: Dr S Yaslikaya, Kanuni Sultan Suleyman Education and Research Hospital Otorhinolaryngology Unit, Istanbul, Turkey. Fax: +902125714790, e-mail: dr.yaslikaya@gmail.com 


\section{INTRODUCTION}

Nowadays, development of industrial production is accompanied by extensive environmental pollution. Various gases of which effects we have not known yet are emitted as a result of industrial production. Although the effects of these gases are not specifically well known, they generally cause air pollution and it is already well known that air pollution exacerbates allergic symptoms (1-3).

Butane gas, a member of saturated aliphatic hydrocarbons, is encountered frequently in daily life, and humans are exposed to it. Butane is a compressed gas that is used as an aerosol propellant in deodorants, shaving foam tubes, air fresheners, and etc. Liquefied petrol gas (LPG) contains butane gas in variable proportions. When we look at the effects of butane gas, acute and high dose inhalation of butane may lead to fatal arrhythmias and sudden death in a healthy heart (4-6). Recent animal studies found out that acute inhalation of extremely high concentrations of butane gas may adversely affect the central nervous system. Scattered symptoms experienced by the animals exposed to high concentration of butane includes headache, nausea, dizziness, drowsiness, confusion, and unconsciousness (7-9). However, there is no study regarding the effects of chronic inhalation of butane gas in the literature.

Allergic rhinitis is a global health problem that negatively influences social life, sleep, school, and occupational life (10). In histopathologic studies concerning allergic rhinitis, once atopy is induced, increase of eosinophils and eosinophil exocytosis, lymphocyte infiltration, and goblet cell hyperplasia have been observed (11-14).

In our study, discovering the effects of butane gas on nasal mucosa in rats and determining its potential allergic effects were aimed. 


\section{SUBJECTS AND METHODS}

This study was conducted in animal laboratory of the Experimental Medical Research Institute of Istanbul University by obeying the Declaration of Helsinki. Prior to the trial, consent from Animal Experiments Local Ethics Committee of Istanbul University was received (Ethics Committee number: 30.03.09-42). In this study, animal experiments ethics board guidelines of Istanbul University were followed.

The study was conducted on 20 healthy adult female Wistar albino rats. Animals were obtained from the animal laboratory of the Experimental Medical Research Institute of Istanbul University. Rats were 7-8 months old, and their weights were varying between 200 and 250 gr. Animals were divided with random choice into two groups of ten, as experimental group and control group. The rats were locked inside the cages so that each cage contains 5 rats. All rats were harbored in a medium which was artificially illuminated and darkened equally for 12 hours. The temperature was set to 21-22 centigrade degrees. The rats were allowed to eat and drink freely. Adjustment of illumination and darkness were carried out by a timer installed to the lighting system. In addition, for the experimental group, an acrylic glass cabin with 20 circular ventilation holes with diameter of $2 \mathrm{~cm}$ and dimensions of 40x40x50 $\mathrm{cm}$ was used. Since rats are more active during night, experimental group was taken into this cabin which placed in another room, in the darkness period. Also an automatic spray machine (Discover automatic spray dispenser; Guler electronic, cosmetic, chemical company, Istanbul, Turkey) with day-night adjustment and timer was installed into the cabin to emit butane gas. During the experiment, lighter gas tubes (Jumbo lighter gas; Unver group, Istanbul, Turkey) that containing purified butane gas were used. Duration of the experiment was determined as 100 days. During the study, butane gas was given as one spray $(0.6 \mathrm{ml})$ in 5-minute intervals during 12-hour darkness period into the cabin where the experimental group was harbored. Gas measurement was held in the geology lab of Istanbul University Faculty of Engineering. 
A gas chromatograph (Agilent 6890N, Agilent technologies, Santa Clara, USA) fitted with a thermal conductivity detector and flame ionization detector was used to identify the hydrocarbon and other noble gases in the cabin.

At the end of the experiment, all animals were sacrificed using intraperitoneal sodium pentobarbital $(100 \mathrm{mg} / \mathrm{kg})$. Then, upper jaws of the animals were removed by incising in front of the orbit on coronal plane as to contain the nose. Five micron-thick coronal slices were taken from the nasal cavities of the animals. Slices were stained with hematoxylin-eosin stains. Decalcification with $20 \%$ formalin-formic acid solution was applied to pieces in order to visualize the goblet cells in slices better for 12 hours. All slices were evaluated microscopically in ten magnified areas in terms of eosinophil count, amount of goblet cells, lymphocyte infiltration, and eosinophil exocytosis (Fig. 1). Most representative magnified areas of cross sections for each cell group were evaluated. Eosinophils in the magnified areas were counted, on the other hand, amount of goblet cells, lymphocyte infiltration, and eosinophil exocytosis were determined semi-quantitatively. During the experiment, two rats from the experiment group and two rats from the control group were died due to unknown reasons. Dead animals were not subjected to histopathological evaluation.

\section{Statistical analyses}

Because of that variables did not provide assumption for normality and numbers of subjects were low in groups, whether histopathological changes differed for the experimental and the control groups was evaluated with Mann-Whitney U test. In addition, relationship between lymphocyte infiltration and eosinophil exocytosis was determined with Pearson Correlation test. The significance level was set at $5 \%(\mathrm{p} \leq 0.05)$ 


\section{RESULTS}

Butane gas is heavier than air and it may accumulate in a closed place. For this reason and due to the ventilation holes of the cabin, amount of butane gas was detected variable in the cabin. In experiment amount of butane gas was detected between 1350-2000 ppm (1.35 - 2\%) in the cabin. Rats showed no symptoms of central nervous system depression.

In the histopathological examination of the slices of the experimental group, it is observed that eosinophil counts vary between 24 and 75 (mean $\pm \mathrm{SD}, 42.4 \pm 18.9$ ). This count ranges from 2 to 9 (mean $\pm \mathrm{SD}, 4.25 \pm 2.8$ ) in the control group. In experimental group, a significant increase was seen in eosinophils $(\mathrm{p}<0.001)$. Amount of goblet cells in slices range between "+" and " +++ " (mean $\pm \mathrm{SD}, 1.75(+) \pm 0.88(+))$ in animals from the experimental group, range from " + " and " ++ " (mean $\pm \mathrm{SD}, 1.125(+) \pm 0.125(+))$ in the control group. When groups were compared, amount of goblet cells was found similar ( $>0.05)$. When lymphocyte infiltration was compared; whereas it ranged from "+" and "++++" (mean $\pm \mathrm{SD}$, $2.25(+) \pm 1.28(+))$ in animals from the experimental group, the range in the control group was found between "+" and "++" (mean $\pm \mathrm{SD}, 1.375(+) \pm 0.517(+))$. When these differences were evaluated, amount of lymphocyte infiltration was found similar ( $p>0.05)$. As for eosinophil exocytosis; whereas values between "+" and "+++" (mean $\pm \mathrm{SD}, 1.875(+) \pm 0.83(+))$ were observed in the experimental group, values between "+" and "++" (mean $\pm \mathrm{SD}, 1.375(+) \pm$ 0.517(+)) were observed in the control group. Eosinophil exocytosis was found similar between groups $(\mathrm{p}>0.05)$ (Table 1). When two groups were compared; in slices which the lymphocyte infiltration was more in the experimental group, eosinophil exocytosis was also found to be more. A positively correlation was observed between lymphocyte infiltration and eosinophil exocytosis in the experimental group $(\mathrm{r}=0,987 \mathrm{p}=0.0001)$. 


\section{DISCUSSION}

There are various gases that are introduced into the atmosphere increasing air pollution. As a result of this, respiratory diseases and allergic diseases may be seen (1-3). Despite an increase in the development of allergic rhinitis with exposure to air pollution $(1-3,15)$, in some other studies this relationship could not be established (16). The relationship between outdoor pollutants and rhinitis of unknown origin has also been reported (17-20). Along with this, it has been claimed that these effects are related with the exposure $(21,22)$. We are exposed to butane gas in many areas of life and effects of this gas on living creatures are not well known.

In literature there are studies about butane gas related generally with acute exposure as accidental or with exposure due to its abuse. When butane gas is inhaled, it makes myocardium sensitive to catecholamines and accumulates in fat rich tissues and especially in brain $(7,23)$. Following the inhalation of butane gas, cases in which occurring ventricular fibrillation and encephalopathy have been reported (6, 24-26). Rhabdomyolysis, multiple organ failure and death due to exposure to butane gas may also develop $(4,5,27,28)$. However, the possible effects of chronic and low-dose exposure to butane gas are not well known. In this study, allergic effects in nasal mucosa of rats as a result of exposing rats to butane gas with low-dose and for longer duration, instead of with acute and high doses, were histopathologically investigated.

Eosinophils and $\mathrm{T}$ lymphocytes are among the major cells of allergic inflammations. In allergic diseases, $\mathrm{T}$ lymphocytes, eosinophils and products have been shown to be increased and found to be related with severity of the disease (29-33). In patients diagnosed with allergic rhinitis, in nasal biopsy and lavage applications a significant increase in numbers and activities of eosinophils and $\mathrm{CD}^{+} \mathrm{T}$ lymphocytes have been found when an allergen is encountered $(11,12)$. It has been shown that in bronchoalveolar lavage fluids taken from 
asthmatic patients 24 hours after allergen is encountered, local $\mathrm{CD}^{+} \mathrm{T}$ lymphocytes were activated, m-RNA expression for $\mathrm{TH}_{2}$-type cytokines was increased and eosinophils piled up (34). Also in experimental studies, eosinophils and $\mathrm{CD}^{+} \mathrm{T}$ lymphocytes are found to be increased in nasal cavity and lungs once allergy is induced $(35,36)$. Additionally CD8+ T lymphocytes are known to have a regulatory role in allergic diseases $(37,38)$. Similarly to these studies, in many slices in experimental group we have observed an increase in eosinophils and lymphocytes in nasal mucosa. The presence of a significant increase $(p<0.001)$ in eosinophils in nasal mucosa shows the relationship of this gas with eosinophilic inflammation. Although there was a more obvious increase in lymphocyte infiltration in the experimental group, this increase was found similar with control group ( $\mathrm{p}>0.05)$. However this result might be related with duration and with the small number of subjects.

The eosinophil exocytosis has an important role in allergic reactions. As a result of exocytosis; cytotoxic proteins such as major basic protein, eosinophil cationic protein, eosinophil peroxidase, eosinophil-derived neurotoxin, enzymes, and also cytokines are released out of the cell, and as a result tissue damage and inflammation develop $(29,39,40)$. In the experimental group, we detected eosinophil exocytosis in many slices. In slices in which lymphocyte infiltration is more, we observed that the eosinophil exocytosis was also more. In the experimental group a positive correlation was observed between the increase in lymphocyte infiltration and the eosinophil exocytosis $(\mathrm{r}=0.987 \mathrm{p}=0.0001)$. This result supported our thought that exposure to butane gas might induce an inflammation.

Goblet cells which form a substantial part of respiratory epithelium are present in almost every site of the mucosa of respiratory tract, and are responsible for production and secretion of mucus. Many inflammatory and humoral mediators that include environmental antigens stimulate mucus production (41). Inflammatory molecules are caused to mucus production from epithelial cells in protective immune response and inflammatory allergic 
airway diseases by activating IL-13 and epidermal growth factor receptor (EGFR). The expression and activation of EGFR promote goblet cell hyperplasia and metaplasia (42, 43). In studies conducted by inducing an allergic inflammation, increase in goblet cells in the respiratory epithelium have been encountered $(13,14,44)$. Also in another study, the amount of goblet cells was found similar in patients with allergic rhinitis both before and after the period of pollens (45). In our study, we encountered increase in goblet cells in many slice areas in the experimental group, but this increase was found insignificant. However a directly proportional relationship has been determined between duration of exposure to antigen and increase in goblet cells (13). We think that butane gas might create an allergic effect on respiratory epithelium if the duration of exposure and the number of subjects increase.

\section{CONCLUSION}

Butane gas is a substance that we frequently encounter in our daily life. Allergic diseases constitute very important health problems worldwide, influence domestic, educational, and social lives of individuals, and account for a significant part in health-care costs. Therefore, eliminating the causes that may have effect on development of allergic diseases is crucial. According to our study, we have concluded that chronic inhalation of butane gas may create inflammation, and might generate allergic effects in nasal mucosa due to significant increase in eosinophils and positively significant correlation between lymphocyte infiltration and eosinophil exocytosis in the experimental group. Although more detailed studies are needed in order to definitively surmise inflammatory and allergic effects of butane gas, our study is significant due to being the first study in the literature. 


\section{ACKNOWLEDGEMENT}

The authors would like to acknowledge the butane gas measurement support provided by Istanbul University Faculty of Engineering department of geology and we thank to Dr Aysenur Igdem for helps about histopathological evaluation.

\section{AUTHORS' NOTE}

S Yaslikaya conducted the experiment, conceived paper, oversaw data collection, conducted data analysis, wrote manuscript and approved final version. I Topaloglu participated in study design, data analysis and interpretation, critically revised manuscript and approved final version. G Hafiz participated in study design, data analysis, and interpretation of data and revision of manuscript and approved final version. The authors declare that they have no conflicts of interest. 


\section{REFERENCES}

1. Yu JH, Lue KH, Lu KH, Sun HL, Lin YH, Chou MC. The relationship of air pollution to the prevalence of allergic diseases in Taichung and Chu-Shan in 2002. J Microbiol Immunol Infect 2005; 38: 123-6.

2. Penard-Morand C, Charpin D, Raherison C, Kopferschmitt C, Caillaud D, Lavaud F, et al. Long- term exposure to background air pollution related to respiratory and allergic health in schoolchildren. Clin Exp Allergy 2005; 35: 1279-87.

3. Hwang BF, Jaakkola JJ, Lee YL, Lin YC, Guo YL. Relation between air pollution and allergic rhinitis in Taiwanese schoolchildren. Respir Res 2006; 7: 23.

4. Sugie H, Sasaki C, Hashimoto C, Takeshita H, Nagai T, Nakamura S et al. Three cases of sudden death due to butane or propane gas inhalation: analysis of tissues for gas components. Forensic Sci Int 2004; 143: 211-4.

5. Rohrig TP. Sudden death due to butane inhalation. Am J Forensic Med and Pathol 1997; 18: 299-302.

6. Edwards KE, Wenstone R. Successful resuscitation from recurrent ventricular fibrillation secondary to butane inhalation. Br J Anaesth 2000; 84: 803-5.

7. Berzins T. Butane. In Nordic council of ministers, eds. Health effects of selected chemicals volume 3. Copenhagen: Nord; 1995: 10-26.

8. Moore AF. Final report of the safety assessment of isobutane, isopentane, n-butane, and propane. Int J Toxicol 1982; 1: 127-42.

9. Galvin JB, Bond G. Isobutane. CAS\# 75-28-5. J Toxicol Environ Health A 1999; 58: $3-22$.

10. Bousquet J, Khaltaev N, Cruz AA, Denburg J, Fokkens WJ, Togias A et al. Allergic rhinitis and its Impact on asthma 2008. Allergy 2008; 86: 8-160. 
11. Ahlstrom - Emanuelsson CA, Greiff L, Andersson M, Persson CGA, Erjefält JS. Eosinophil degranulation status in allergic rhinitis: observations before and during seasonal allergen exposure. Eur Respir J 2004; 24: 750-7.

12. Durham SR, Ying S, Varney VA, Jacobson MR, Sudderick RM, Mackay IS et al. Grass pollen immunotherapy inhibits allergen induced infiltration of CD4+ T lymphocytes and eoshinophils in the nasal mucosa and increases the number of cells expressing messenger RNA for interferon- gamma. J Allergy Clin Immunol 1996; 97: 1356-65.

13. Nakaya M, Dohi M, Okunishi K, Nakagome K, Tanaka R, Imamura $M$ et al. Prolonged allergen challenge in murine nasal allergic rhinitis: nasal airway remodeling and adaptation of nasal airway responsiveness. Laryngoscope 2007; 117: 881-5.

14. Wagner JG, Jiang Q, Harkema JR, Ames BN, Illek B, Roubey RA et al. $\gamma$-Tocopherol prevents airway eosinophilia and mucous cell hyperplasia in experimentally induced allergic rhinitis and asthma. Clin Exper Allergy 2007; 38: 501-11.

15. de Marco R, Poli A, Ferrari M, Accordini S, Giammanco G, Bugiani M et al. The impact of climate and traffic related $\mathrm{NO} 2$ on the prevalence of asthma and allergic rhinitis in Italy. Clin Exp Allergy 2002; 32: 1405-12.

16. Keles N, Ilicali C, Deger K. The effects of different levels of air pollution on atopy and symptoms of allergic rhinitis. Am J Rhinol 1999; 13: 185-90.

17. Premaratna R, Pathmeswaran A, Chandrasekara B, Dissanayake AS, de Silva HJ. Effects of pollution on health of residents in an industrial area in Sri Lanka. Arch Environ Health 2002; 57: 579-83.

18. Sichletidis L, Tsiotsios I, Gavriilidis A, Chloros D, Gioulekas D, Kottakis I et al. The effects of environmental pollution on the respiratory system of children in western Macedonia, Greece. J Investig Allergol Clin Immunol 2005; 15: 117-23. 
19. Wongsurakiat $\mathrm{P}$, Maranetra $\mathrm{KN}$, Nana A, Naruman C, Aksornint M, Chalermsanyakorn T. Respiratory symptoms and pulmonary function of traffic policemen in Thonburi. J Med Assoc Thai 1999; 82: 435-43.

20. Chen PC, Lai YM, Wang JD, Yang CY, Hwang JS, Kuo HW et al. Adverse effect of air pollution on respiratory health of primary school children in Taiwan. Environ Health Perspect 1998; 106: 331-5.

21. Corbo GM, Forastiere F, Dell'Orco V, Pistelli R, Agabiti N, De Stefanis B et al. Effects of environment on atopic status and respiratory disorders in children. J Allergy Clin Immunol 1993; 92: 616-23.

22. Kuehni CE, Strippoli MP, Zwahlen M, Silverman M. Association between reported exposure to road traffic and respiratory symptoms in children: evidence of bias. Int $\mathbf{J}$ Epidemiol 2006; 35: 779-86.

23. Snyder R. Ethel Browning's toxicity and metabolism of industrial solvents: hydrocarbons. Amsterdam: Elsevier; 1987.

24. Lovecchio F, Fulton SE. Ventricular fibrillation following inhalation of glade air freshener. Eur J Emerg Med 2001; 8: 153-4.

25. Harris D, Mirza Z. Butane encephalopathy. Emerg Med J 2005; 22: 676-7.

26. Kile SJ, Camilleri CC, Latchaw RE, Tharp BR. Bithalamic lesions of butane encephalopathy. Pediatr Neurol 2006; 35: 439-41.

27. Frangides CY, Tzortzatos GV, Koulouras V, Pneumatikos IA. Acute massive rhabdomyolysis due to prolonged inhalation of liquid gas. Eur J Emerg Med 2003; 10: 44-6.

28. Rieder-Scharinger J, Peer R, Rabl W, Hasibeder W, Schobersberger W. Multiple organ failure following inhalation of butane gas: a case report. Wien Klin Woshenschr 2000; 112: 1049-52. 
29. Rothenberg M E. Eosinophilia. N Engl J Med 1998; 338: 1592-600.

30. Filley WV, Holley KE, Kephart GM, Gleich GJ. Identification by immunofluorescence of eosinophil granule major basic protein in lung tissues of patients with bronchial asthma. Lancet 1982; 2: 11-6.

31. Fujimoto K, Kubo K, Matsuzawa Y, Sekiguchi M. Eosinophil cationic protein levels in induced sputum correlate with the severity of bronchial asthma. Chest 1997; 112: 1241-7.

32. Woodfolk JA. T Cell Responses to allergens. J Allergy Clin Imminol 2007; 119: 28094.

33. Paulnock D, Springer T, Jenkins MK, Tschopp J, Steinman R. T cell mediated immunity. In Janeway CA, Travers P, Walport M, Shlomchik MJ, eds. Immunobiology. New York: Garland Publishing; 2001: 341-99.

34. Robinson D, Hamid Q, Andrew B, Ying S, Kay AB, Durham SR. Activation of CD4+ T cells Increased TH2- type cytokine m-RNA expression and eosinophil recruitment in bronchoalveolar lavage after allergen inhalation challenge in patients with atopic asthma. J Allergy Clin Immunol 1993; 92: 313-24.

35. Brozmanova M, Bartos V, Plank L, Tatar M. Experimental allergic rhinitis-related cough and airway eosinophilia in sensitized guinea pigs. J Physiol Pharmacol 2007; 58: $57-65$.

36. Li J, Saito H, Crawford L, Inman M D, Cyr M M, Denburg J A. Haemopoietic mechanisms in murine allergic upper and lower airway inflammation. Immunology 2005; 114: 386-96.

37. Seneviratne SL, Jones L, King AS, Black A, Powell S, Mc Michael AJ et al. Allergenspecific CD8+ T cells and atopic disease. J. Clin. Invest 2002; 110: 1283-91. 
38. Stock P, Kallinich T, Akbari O, Quarcoo D, Gerhold K, Wahn U et al. CD8+ T cells regulate immune responses in a murine model of allergen-induced sensitization and airway inflammation. Eur J Imminol 2004; 34: 1817-27.

39. Spencer LA, Bonjour K, Melo RC, Weller PF. Eosinophil secretion of granule-derived cytokines. Front Immunol 2014; 5: 496.

40. Clark K, Simson L, Newcombe N, Koskinen AML, Mattes J, Lee NA et al. eosinophil degranulation in the allergic lung of mice primarily occurs in the airway lumen. $\mathbf{J}$ Leukoc Biol 2004; 75: 1001-9.

41. Martin LD, Rochelle LG, Fischer BM, Krunkosky TM, Adler KB. Airway epithelium as an effector of inflammation: molecular regulation of secondary mediators. Eur Respir J 1997; 10: 2139-46.

42. Abraham CM, Ownby DR, Peterson EL, Wegienka G, Zoratti EM, Williams LK et al. The relationship between seroatopy and symptoms of either allergic rhinitis or asthma. J Allergy Clin Immunol 2007; 119: 1099-104.

43. Nadel JA. Innate immune mucin production via epithelial cell surface signaling: relationship to allergic disease. Curr Opin Allergy Immunol 2007; 7: 57-67.

44. Olmez D, Babayigit A, Erbil G, Karaman O, Bagriyanik A, Yilmaz O et al. Histopathologic changes in two mouse models of asthma. J Investig Allergol Clin Immunol. 2009; 19: 132-8.

45. Guluck U, Gebbers J. Epithelial changes in seasonal allergic rhinitis throughout the year: evidence of coexistent air pollution and local secretory IGA deficiency? ORL 2000; 62: 68-75. 
Table 1:. Histopathologic changes in nasal mucosa between experimental and control groups

\begin{tabular}{|c|c|c|c|c|c|c|c|c|c|}
\hline & $\begin{array}{l}\text { 1st } \\
\text { Rat }\end{array}$ & $\begin{array}{l}\text { 2nd } \\
\text { Rat }\end{array}$ & $\begin{array}{l}\text { 3rd } \\
\text { Rat }\end{array}$ & $\begin{array}{l}\text { 4th } \\
\text { Rat }\end{array}$ & $\begin{array}{l}\text { 5th } \\
\text { Rat }\end{array}$ & $\begin{array}{l}\text { 6th } \\
\text { Rat }\end{array}$ & $\begin{array}{l}\text { 7th } \\
\text { Rat }\end{array}$ & $\begin{array}{l}\text { 8th } \\
\text { Rat }\end{array}$ & p-value \\
\hline $\begin{array}{c}\text { Eosinophil } \\
\text { counts in } \\
\text { E.G }\end{array}$ & 30 & 32 & 65 & 28 & 24 & 75 & 50 & 35 & $<0.0001$ \\
\hline $\begin{array}{c}\text { Eosinophil } \\
\text { counts in } \\
\text { C.G }\end{array}$ & 3 & 2 & 2 & 5 & 9 & 8 & 2 & 3 & \\
\hline $\begin{array}{c}\text { Amounts } \\
\text { of goblet } \\
\text { cells in E.G }\end{array}$ & + & + & + & ++ & ++ & +++ & + & +++ & NS \\
\hline $\begin{array}{c}\text { Amounts } \\
\text { of goblet } \\
\text { cells in C.G }\end{array}$ & + & + & ++ & + & + & + & + & + & \\
\hline $\begin{array}{c}\text { Amounts } \\
\text { of } \\
\text { lymphocyte } \\
\text { infiltration } \\
\text { in E.G }\end{array}$ & ++++ & ++++ & ++ & ++ & + & + & +++ & + & NS \\
\hline $\begin{array}{c}\text { Amounts } \\
\text { of } \\
\text { lymphocyte } \\
\text { infiltration } \\
\text { in C.G }\end{array}$ & + & + & + & ++ & ++ & ++ & + & + & \\
\hline $\begin{array}{l}\text { Amounts } \\
\text { of } \\
\text { eosinophil } \\
\text { exocytosis } \\
\text { in E.G }\end{array}$ & +++ & +++ & ++ & ++ & + & + & ++ & + & NS \\
\hline $\begin{array}{l}\text { Amounts } \\
\text { of } \\
\text { eosinophil } \\
\text { exocytosis } \\
\text { in C.G }\end{array}$ & + & + & + & ++ & ++ & ++ & + & + & \\
\hline
\end{tabular}




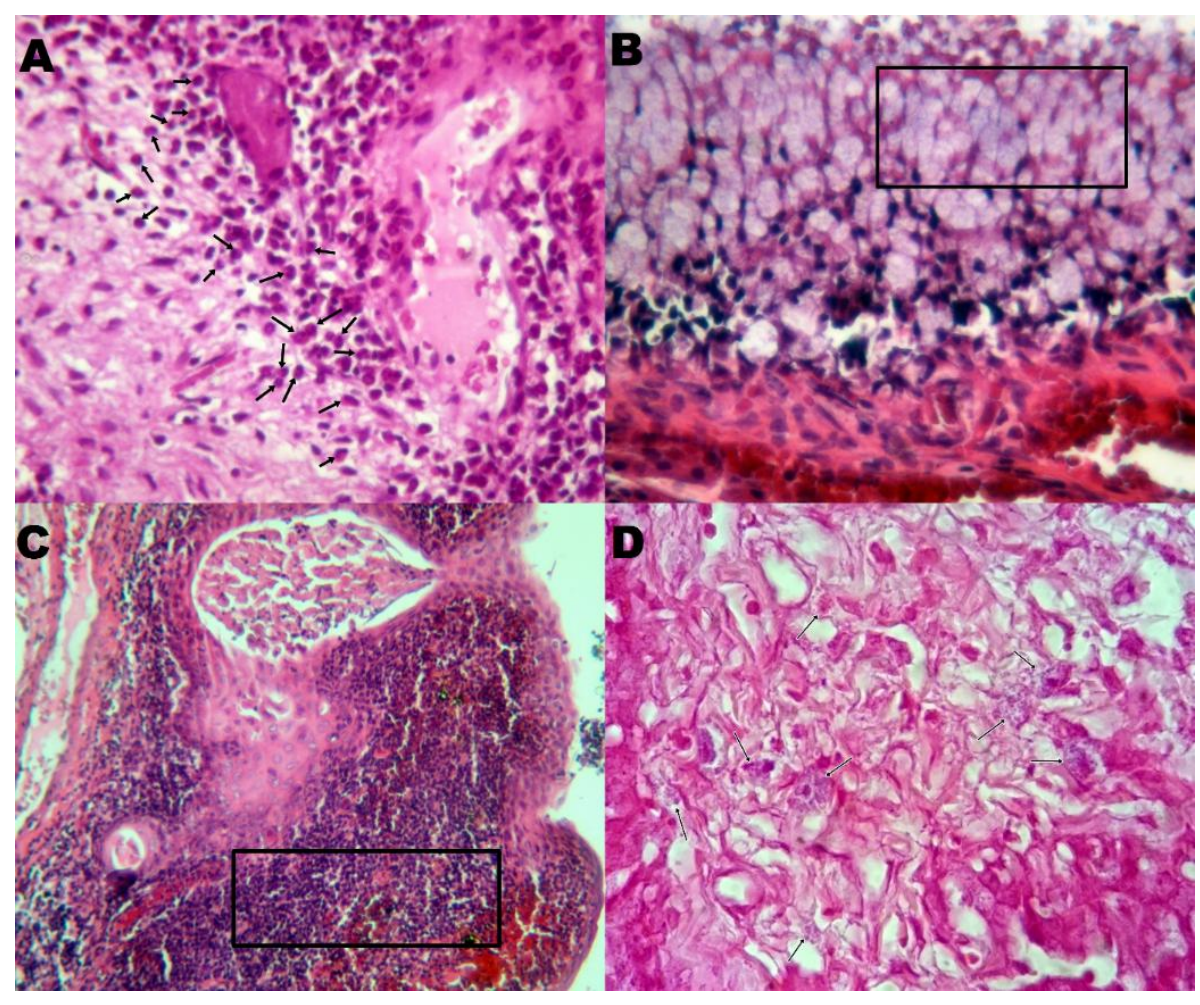

Fig. 1: A: Eosinophilia in nasal mucosa. Arrows show some of the eosinophils (experimental group; hematoxylin - eosin stains, magnification $\times 100$ ).

B: Goblet cells in nasal epithelia. Inside the rectangle a group of goblet cell is seen with translucent cytoplasm (experimental group; hematoxylin - eosin stains, magnification $\times 400$ ). C: Lymphocyte infiltration in nasal mucosa. A large number of lymphocytes are seen inside the rectangle (experimental group; hematoxylin - eosin stains, magnification $\times 100$ ).

D: Eosinophil exocytosis in nasal mucosa. Arrows show some of the exocytosis areas (experimental group; hematoxylin - eosin stains, immersion magnification $\times 1000$ ). 